\title{
Change of regional water chemistry driven by group coal mining in Changzhi basin, Shanxi, China
}

\author{
Zhantao Han ${ }^{1, *}$, Fawang Zhang ${ }^{2}$, and Hongchao $\mathrm{Yao}^{1}$ \\ ${ }^{1}$ Institute of Hydrogeology and Environmental Geology, Chinese Academy of Geological Sciences, \\ 050061 Shijiazhuang, China \\ ${ }^{2}$ Institute of Karst Geology, Chinese Academy of Geological Sciences, 541004 Guilin, China
}

\begin{abstract}
Coal mining can deplete groundwater resources and discharge polluted water into the surrounding water bodies, decreasing the quality of ground and surface water. Group coal mining can drastically deteriorate regional water quality due to the overlying effects of multiple mines. As a country, China produces the most coal per year in the world. Group coal mining in China has caused a decline in the quality of many watersheds. This study introduced the regional water quality in Changchi basin, Shanxi province, which contains coal seams covering over $60 \%$ of its area and has over 10 active collieries. Coal mine discharge caused the increase of TDS, especially $\mathrm{NO}_{3}$, in the river receiving the mining discharge. Quality of groundwater was also affected by the contaminated surface water when it was recharged by surface water. Reuse and treatment of mining discharged should be promoted in the area with high intensity of group coal mining.
\end{abstract}

\section{Introduction}

Water pollution caused by coal mining is a worldwide environment problem[1]. The water rock interaction during groundwater flow through the fresh fissures in collapsed or deformed strata is very intensive, especially when soluble salts or oxidizable elements such as sulfur exist in the strata[2]. In the large coal fields in China, there are usually many collieries in operation at the same time[3]. This group coal mining activity drastically affected the flowing field and chemistry of the regional water system[3]. Acid mining discharge with significant low $\mathrm{pH}$ and high sulfate, high hardness, and occasionally high heavy metal can pollute the regional water system drastically[4].

In this paper, the change of regional water chemistry with the development of group coal mining in Changzhi basin, Shanxi province of China was introduced, how the coal industry affected the regional water chemistry was analyzed, and feasible measures for water pollution prevention was proposed.

\footnotetext{
* Corresponding author: hanzhantao1977@163.com
} 


\section{Study area}

Changzhi basin is a Cenozoic graben basin located in the southeast of Shanxi province with mountains surrounding its four sides. Our study area covered the entire Lu'an coal mining district, located at the center of Changzhi basin. The north and west borders of the studied area are the border of the plain. Zhuozhang river flows across the basin from south to north and was the east border of the study area. Lanshui river which is a branch of Zhuozhang river, was the south border of the studied area.

The main strata in the study area include Ordovician limestone, Carbonic coal containing sandstone and mudstone, Permian and Triassic sandstone and mudstone, and Quaternary fluvial and lacustrine sediments. There are seven main coal mines (Yuwu, Wangzhuang, Changcun, Guozhuang, Shigejie, Gucheng and Zhangcun) and some small coal mines in the Lu'an coal mining district.The 3rd coal seam in upper Carbonic strata is the main excavated coal seam all across the mining district, the burying depth of the 3rd coal seam to the ground surface is about $700 \mathrm{~m}$, and the height of the fractured zone caused by coal mining is about $100-120 \mathrm{~m}$. There are three main aquifers on the top of the $3 \mathrm{rd}$ coal seam, including the Shanxi group sandstone aquifer and the Shihezi group sandstone aquifer in the Lower Permian, and the Quaternary aquifer. The vertical distance of the 3 aquifers to the 3 rd coal seam are about $300-600 \mathrm{~m}, 50-160 \mathrm{~m}$, and 20-90 m, respectively. Clay stone aquitards laying between the aquifers, separating the hydraulic connection between the aquifers.

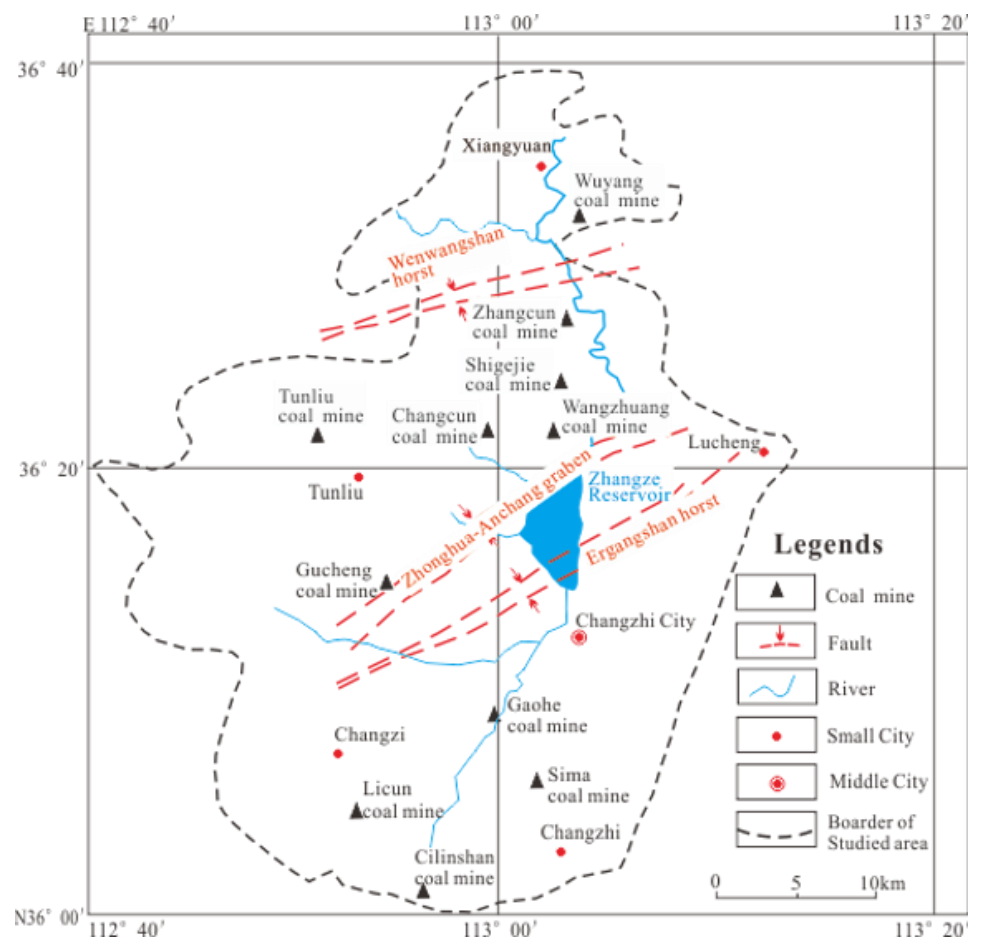

Fig. 1. Sketch map of the study area. 


\section{Water sampling and data collection}

\subsection{Water sampling}

A total of 32 water samples were collected from the Zhuozhang and Lanshui rivers, the groundwater in Permian sandstone, Carbonic limestone and Ordovician limestone aquifers, and the pit water in the mining tunnels. The locations of different types of water samples were shown in Fig. 2. The $\mathrm{pH}$ values were tested in situ. The concentration of $\mathrm{Ca}^{2+}, \mathrm{Mg}^{2+}$, $\mathrm{K}^{+}$and $\mathrm{Na}^{+}$were tested in lab by inductively coupled plasma mass spectrometry (Agilent 7800 ), $\mathrm{Cl}^{-}, \mathrm{SO}_{4}{ }^{2-}$ and $\mathrm{NO}_{3}{ }^{-}$were tested by ion chromatography (Dionex ICS-1100), $\mathrm{HCO}_{3}{ }^{-}$, and $\mathrm{CO}_{3}{ }^{-}$were tested by titration (Chinese standard DZ/T0064-1993). 20\% samples were duplicated and the relative deviations between duplicated samples were controlled to bellow $20 \%$.

\subsection{Data collection}

Ten of the groundwater chemical composition test results were collected from the hydrogeological team of Lu'an Group, The locations of these collected groundwater samples were also shown in Fig. 2. The mining water discharge records were collected from different collieries.

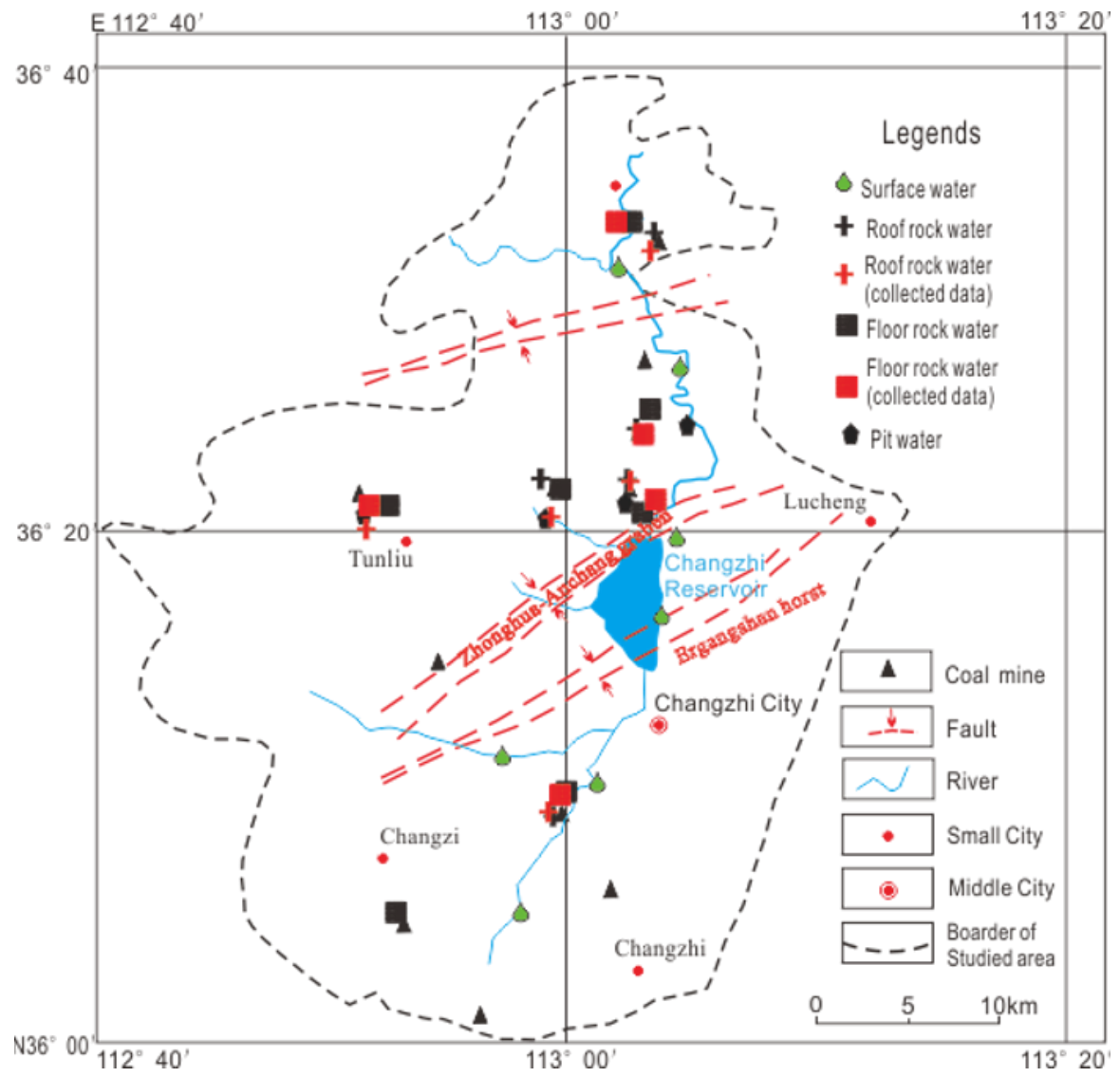

Fig.2. Sampling sites of groundwater and surface water. 


\section{Regional water chemistry and their relation to coal mining}

\subsection{Regional groundwater chemistry}

The groundwater in the Quaternary aquifer, the Permian sandstone aquifer, and the Ordovician limestone aquifer has different hydrochemistry type (Fig.3). Quaternary groundwater is of $\mathrm{HCO}_{3}$-Ca type, with total dissolved solids (TDS) of 400-700 mg/L; groundwater in Permian sandstone is of $\mathrm{HCO}_{3}-\mathrm{Na}$ type, with TDS of 700-1000 mg/L; while groundwater in Ordovician limestone is of $\mathrm{SO}_{4}-\mathrm{Ca}$ or $\mathrm{SO}_{4} \cdot \mathrm{HCO}_{3}-\mathrm{Ca}$ type, with TDS of $800-1500 \mathrm{mg} / \mathrm{L}$. The $\mathrm{pH}$ values of these groundwater are larger than 7.5 which reflects the regional alkaline environment. The groundwater in Permian sandstone is recharged by Quaternary groundwater, and the $\mathrm{Ca}^{2+}$ in Quaternary groundwater was exchanged with $\mathrm{Na}^{+}$ through cation exchange between the groundwater and the aquifer materials. The $\mathrm{SO}_{4}-\mathrm{Ca}$ type water of Ordovician limestone is quite strange, but according to the studies of other Ordovician limestone groundwater in other area such as Yangquan city[5], both the dissolution of gypsum and the recharge of acid pit water can contribute to the enrichment of sulphate in karst water. For the groundwater in Ordovician aquifer in this study, the dissolution of gypsum should be the main source of sulphate since no significant acid pit water was found in this basin[6].

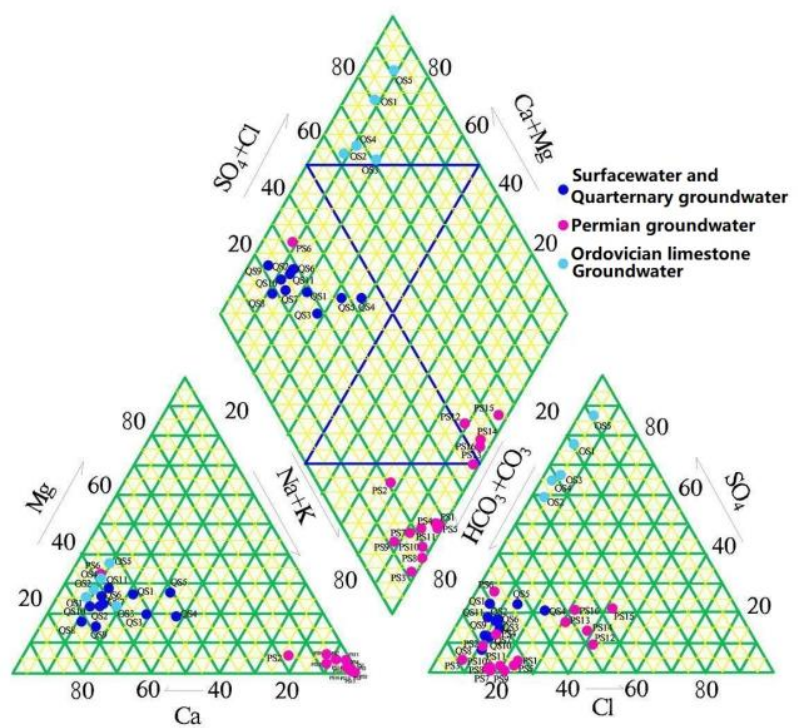

Fig. 3. Piper trilinear diagram of the ground and surface water in the study area.

The chemical compositions of pit water showed wide variety, but are mainly of $\mathrm{HCO}_{3}-\mathrm{Na}$ type and with TDS of around $800 \mathrm{mg} / \mathrm{L}$. This is because the pit water are mainly the leakage water from Permian sandstone aquifer and a small part from the Ordovician limestone groundwater pumped out for dust elimination and other purposes in the tunnels.

\subsection{Regional surface water chemistry}

All the surface water in the Changzhi basin belongs to the Zhanghe river system. The TDS of water from Zhanghe river and its tributaries showed a steady increase from upstream to downstream, while a sharp increase in $\mathrm{Cl}^{-}, \mathrm{SO}_{4}{ }^{2-}$ and $\mathrm{NO}_{3}{ }^{-}$happened when mine water was 
discharged into the river. Municipal waste water discharge and the run off from farmlands also contain high concentrations of $\mathrm{NO}_{3}{ }^{-[7]}$, which, in additions to the contributions from the mining discharge, could explain the high concentrations of $\mathrm{NO}_{3}$.

\subsection{How group coal mining affects the regional water chemistry}

Coal mining depleted the groundwater in the Carbonaceous coal seams and the Permian sandstone within the collapsed zone and fractured zone. The depleted groundwater was contaminated in the tunnels, treated, and reused,with part of it discharged into surface water. The average water discharge in all the collieries are $0.3-0.7 \mathrm{~m}^{3}$ per tone of coal production. The intensive group coal mining activity discharged a much larger volume of waste water into the surface water system, and caused the increase of $\mathrm{SO}_{4}{ }^{2-}$ and $\mathrm{NO}_{3}{ }^{-}$in much larger area. Groundwater quality in some places were also deteriorated when recharged by contaminated surface water which has relative high concentration of $\mathrm{NO}_{3}{ }^{-}$of about 20-50 $\mathrm{mg} / \mathrm{L}$. This happened in some places when the river ran across the water conductive faults.

\section{Conclusion and suggestions}

The effects of group coal mining on regional water chemistry was investigated in Changzhi basin, Shanxi, China. Coal mining mainly affected the regional water system by discharging contaminated pit water into the surface water body. Mining discharge has high TDS and high $\mathrm{NO}_{3}{ }^{-}$, which are difficult to be removed by flocculation and sedimentation. Compared with single colliery, group coal mining discharged a much larger volume of waste water and caused water quality deterioration in a larger area and with higher intensity. Raising the rate of reusing mining water discharge, and improving the mine water treatment, are clearly effective ways of protecting the water quality from mine water contamination.

Acknowledgement.This research work was financially supported by National Natural Science Foundation of China (41130637).

\section{References}

1. H. Anawar, Phys \& Chem of the Earth 58-60 (2013)

2. A. Manna, R.Maiti, Geosci Frontiers, 1577-1590 (2017)

3. P. Liu, N. Hoth, C. Drebenstedt, et al, Sci. Total Environ. 601-602 (2017)

4. F. Silval, F. Vallejuelo, I. Martinez-Arkarazo, et al., Sci. Total Environ. 447 (2013)

5. X. Fang, Y. Fu, Proce Ear Planet Sci. 3 (2011)

6. W. Qiao, Q. Liu, X. LI, et al., Res Pol (2018)

7. Q. Wu, L. Xing, W. Zhou, Groundwater Hydrology of Springs (Boston, ButterworthHeinemann, 2010) 